\title{
Investigation of Excellent Performance for Basic Accounting Course: The Evidence of Non-Accounting Students
}

\author{
Nur Farahah Mohd Pauzi ${ }^{1}$, Adriana Shamsudin ${ }^{2}$, Nurfarahin Roslan ${ }^{3}$, Mohd Syazwan Karim ${ }^{4}$, \\ Khairiah Ahmad $^{5}$ \\ \{adriana416@uitm.edu.my $\left.{ }^{2}\right\}$ \\ Universiti Teknologi MARA, Malaysia' ${ }^{1,2,3,4,5}$
}

\begin{abstract}
Nowadays, graduates should focus more on entrepreneurship rather than being employed due to the rise of unemployment rate in Malaysia. Accounting literacy is a key role in the success of being an entrepreneur. However, non-accounting students believed that accounting subject as irrelevant to their discipline and difficult to grasp due to its technical and complex process. This perception has consequently led to a high failure rate of accounting subject among non-accounting students. On the other hand, most of the nonaccounting students in Universiti Teknologi MARA Jasin Campus had performed very well in the accounting subject. The characteristics of students such as their past experiences and their approaches to learning may influence the academic performance in the basic accounting course. Hence, this study examines the factors that contribute to the student's excellence performance for the basic accounting course. 524 students from two faculties responded to the questionnaire distributed. Findings of this study revealed that, those students with prior accounting knowledge performed better and have a high success rate in the basic accounting course. Besides, basic understanding in the financial statements components significantly affect the performance of non-accounting students. These results indicate that prior accounting knowledge really helps students to excel in accounting courses which are necessary to prepare them as an entrepreneur after they have graduated.
\end{abstract}

Keywords: Accounting Course, Accounting Background, Non-Accounting Students, Performance, Prior Accounting Knowledge

\section{Introduction}

To date, Malaysia is facing an upward trend of youth unemployment rate from 10.77 per cent in 2017 to 10.92 per cent in 2018 [1]. In line with the current issue, the government has always come out with the current program that focuses on entrepreneurship with the ultimate aim to produce more entrepreneurs or job creators among the graduates [2]. According to Umeji \& Obi [3], accounting literacy is a key role in the success and failure of the business. Hence, Universiti Teknologi MARA (UiTM) on the other side has made the parallel effort by requiring the basic accounting course, ACC 106: Introduction to Financial Accounting and Reporting as a compulsory subject for almost all diploma courses in order to equip students with basic knowledge on accounting. The requirement entry for almost all diploma courses is that candidates must pass Malaysian Certificate of Education (SPM) or O-level or equivalent 
qualifications recognized by the Government of Malaysia with four credits subjects including English and Mathematics.

The content of the course would comprise of nine (9) basic accounting areas which comprise of accounting concepts, accounting classification, principle of double entry, ledger, trial balance, financial statement, year-end adjustment, bank reconciliation and ratio analysis. Students are tested with 40 per cent continuous assessment and 60 per cent final examination. This course can be considered as an advantage and repetitive to those students who have taken Prinsip Perakauan during SPM level at secondary school. The basic accounting knowledge embedded in ACC106 is sufficient for graduates to practically apply the knowledge if they want to start their own business.

Prior studies have revealed that non-accounting students believed the accounting subject as irrelevant to their discipline and difficult to grasp due to its technical and complex process. This consequently led to failure to perform accounting courses by a number of non-accounting students [4]. However, most of the non-accounting students particularly in UiTM Melaka Branch, Jasin Campus performed well in this subject even though they never studied any accounting subject before. Currently, the success rate for non-accounting students taking ACC106 was 93\% (passed the papers).

Even though accounting is perceived as difficult, introductory accounting courses are important to be taught to non-accounting students as knowledge and skills are necessary for lifelong learning [5]. Attracting students' interest into accounting has been recognized as seriously vital in the development of skills necessary to be successful in both accounting and non-accounting professions [6][7]. According to Biggs [8] model of student learning process, performance or output of a subject matter are outlined by characteristics of students and their learning approaches. Appropriate study skills with the appropriate teaching and learning approach will make the students understand better of their subjects of any disciplines.

Inspired by this phenomenon, this paper attempts to investigate the factors contributing to the high success rate for basic accounting subjects, ACC106 including characteristics of students such as their past experiences and their approaches to learning that may influence the academic performance of the non-accounting students in the basic accounting course. The unique contribution of this study is that it discusses the evidence on the factors, specifically the understanding of financial statement components; affecting the success of students taking courses that are distinct from their major discipline.

\section{Literature Review}

\subsection{The Importance of Accounting Subject}

In the early 1960s, researchers struggled to determine the essential accounting course offered to non-accounting students [9]. Some educators believed a separate course should be established for non-accounting students as compared to accounting major students [9]. Accounting is seen as the language of the business [10]. Since the beginning of civilized society, accounting has played a crucial role in society. Accounting is important to analyse how money is used by business. If anything related about money, it starts with accounting [11].

In UiTM, Accounting subjects are not only offered to accounting students. Other programs such as Business, Plantation, Computer Science have included this accounting subject either as a compulsory or elective course. In fact, the mission of UiTM to produce excellence and independent students not only to become job seekers but make them a job creator or 
entrepreneur. This is in accordance with Ahmad \& Xavier [12] which revealed that entrepreneurship activities produce employment, generate wealth and inspire economic development. Entrepreneurship is considered vital in the revolution of nations, politically and socio-economically [13]. Thus, in order for students to become entrepreneurs in the future, universities must equip their students with basic accounting courses.

Throughout the years, many studies related to the factors influencing the performance of the non-accounting students have been conducted. Despite the importance of accounting subjects, non-accounting students did not perform well in the accounting course [4][14]. Non accounting students perceived accounting courses irrelevant to their discipline and were not interested in accounting subjects. In addition, the learning style and background of nonaccounting students are also different from accounting students [15]. A study revealed that students who are not equipped with strong mathematical skills do not perform in accounting subjects [16]. Eskew and Faley [17] found that students with previous accounting exposure in high school tend to perform well in accounting subjects.

Regardless of the negative performance of the non-accounting students, some of the recent studies suggested various teaching and learning strategies to non-accounting majors to help them to get good results in accounting course [18][19][20]. Evidences shown various styles of learning and teaching techniques should be introduced such as active learning, deep, surface and strategy approach. Ismail \& Kasim [21] suggested accounting courses should be offered to higher level non-accounting students. The result indicates that it is possible for students who do not have accounting background to obtain a high score in the accounting subject. In accordance to Baldwin \& Howe [22], students' performance is not significantly associated with prior exposure in high school accounting education. That means even though students do not have a prior accounting background they still can score in accounting. Muda et al. [19] revealed that from the examination results they obtained; it was reported 53.8\% students passed ACC106 subject among non-accounting students in UiTM Negeri Sembilan. The result indicated the percentage of passed was more than failure even though the percentage of failure was quite high. Hence, this study will investigate factors contributing to the high success rate for basic accounting subjects among non- accounting students in UiTM Jasin.

\subsection{Component of Subject Introduction to Financial Accounting (ACC106)}

UiTM requires students to register subject Introduction to Financial Accounting (ACC106) during second semester as elective subject for Diploma in Computer Science and during third semester for students in Diploma in Plantation Management (AT110) as compulsory subject. This subject provides a fundamental of Accounting Concept, Journals, Ledgers, Trial Balance, Financial Statement, Adjusted Financial Statement, Bank Reconciliation, and Accounting Ratio for sole traders [19].

\section{Research Methodology}

\subsection{Sample and Data Collection}

A set of questionnaires was distributed to all non-accounting students sitting for subject ACC106 (Introduction to Financial Accounting and Reporting) from UiTM Melaka Branch, Jasin Campus. The samples were selected based on cluster sampling. A total number of populations is divided into groups called clusters. In Malaysia a total of 9,340 students from 
fourteen (14) UiTM branches all over Malaysia have taken ACC106 subject. We focus on one of the branches (cluster) which is in Jasin Campus, Malacca as our aim mainly to investigate on the factors contributing to the high success rate among our students. This cluster contributes a total number of 524 students which constitutes 270 of third semester students from the Faculty of Plantation and Agrotechnology and another 254 of first semester students from the Faculty of Computer Science and Mathematics. The current study is unique as it discusses the evidence on the factors, specifically the understanding of financial statement components; affecting the success of students taking courses that are distinct from their major discipline. The survey method would be the best approach to explore opinions and gain perceptions of respondents as it is less expensive and less time consuming [23].

\subsection{Data Measurement \& Analysis}

The current research employed Statistical Package for Social Sciences (SPSS) version 25.0 to analyse the data. We present the statistical information through a graphical form for descriptive statistics to portray samples and population of research. The current research also tested the difference between the mean of two independent samples using independent t-test towards the performance of the students. The samples were divided into two categories which are (i) students who have an accounting background from secondary school which denoted as 'YES' and (ii) students who do not have any accounting knowledge and background from secondary school which denoted as 'NO'. The performance of students was measured by looking at their final examination results in ACC106 subject. The measurement of students' performance using final examination results is consistent with research done by Muda et al. [19]. The present study further extends the research through multiple linear regressions to assess whether the components of financial statements contribute to students' understanding which finally lead to students' performance. Multiple linear regression helps the researcher to identify which factor will give influence on students' performance [20]. There are four main components of financial statements which are (i) revenues (ii) expenses (ii) assets and (iv) owner's equity and liabilities. The responses are based on the 5-point Likert scale indicating "1-Poor, 2-Fair, 3Average, 4-Good and 5-Excellent".

\subsection{Development of Questionnaire}

The present study used questionnaires as an instrument for data collection. This questionnaire was distributed to the students at the end of the semester before they sit for their final examination. The design of the questionnaires covered four sections. A summary of the main sections of the questionnaire is shown in table 1 below.

Table 1. Summary of Items in Survey Questionnaire

\begin{tabular}{ll}
\hline Section A: Background of the students \\
\hline 1. & Cumulative Grade Point Average (CGPA) \\
2. Accounting background from secondary school \\
3. English results from secondary school \\
4. Family members with accounting profession \\
5. Previous accounting knowledge \\
\hline Section B: Components of Financial Statements \\
\hline Section 1: Business Revenues \\
1. \\
2. Devenues was shown in Statement of Profit or Loss
\end{tabular}


3. Other revenues

4. Example of revenues

5. Items under revenues

Section 2: Business Expenses

1. Definition of expenses

2. Effect of expenses on net profit

3. Example of expenses

4. Items under expenses

Section 3: Business Assets

1. Definition of Assets

2. Examples of Assets

3. Items of Assets under Statement of Financial Position

4. Description of Assets

5. Types of Assets

Section 4: Owner's Equity and Liabilities

1. Effect of owner's equity on accounting equation

2. Component of Owner's Equity

3. Types of Liabilities

4. Items of Liabilities

5. Examples of Liabilities

\section{Findings and Discussion}

\subsection{Demographic Profile}

Questionnaires were distributed to students in UiTM Melaka Branch, Jasin Campus who were compulsory to take the subject of ACC106 at diploma level for the Semester of September 2018 to January 2019. A total number of 524 students responded to the survey. 48 per cent (254) of the students were from Diploma in Science Computer (CS110) whereby 52 per cent (270) of the students were from Diploma in Planting Industry Management (AT110). Both faculties are from science clusters and the requirements to enrol this two (2) courses were quite high. Students should have possessed at least credit in Mathematics during secondary school level in which accounting is a calculative subject and thus requires basic in calculation.

\section{Student who take Accounting in SPM level}

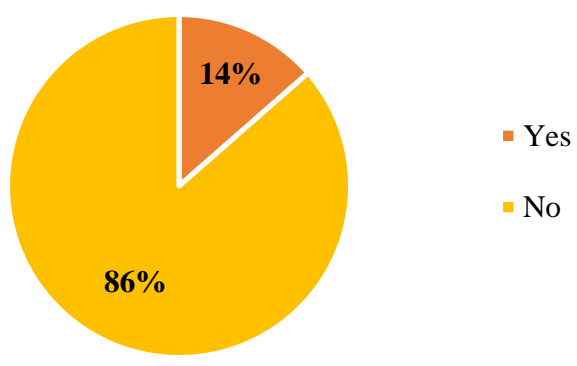

Fig. 1. Students who have Knowledge in Accounting during secondary level. 
Based on Figure 1, 14 per cent (71) of the students have taken Prinsip Perakaunan during SPM level which could be an advantage to this group of students. However, at diploma level they have to learn an accounting subject in English language as compared to SPM level whereby they have been taught in Bahasa Melayu. Apart from that, 20 percent (103) of the students have basic accounting knowledge either from formal sources or informal sources (Figure 2).

\section{Student who has knowledge in Accounting}

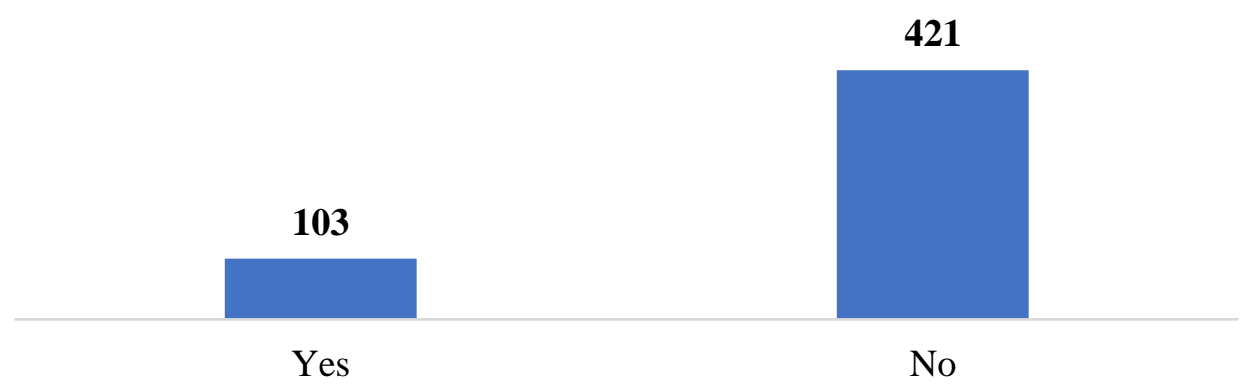

Fig. 2. Students who have Knowledge in Accounting (Formal and Informal Sources).

From 524 students, 48 per cent (252) of the students scored A-, A and A+ for this course, 31 per cent (161) of the students scored B-, B and B+ and 14 per cent (72) of the students scored $\mathrm{C}$ and $\mathrm{C}+$. Meanwhile, only 7 per cent (39) of the students failed this course.

Cronbach's alpha was used to measure the internal consistency between the questions in one similar group. The reliability coefficient normally ranges between 0 to 1 . The higher the value of the Cronbach's Alpha, the more reliable the test is. We have tested the reliability of the components of financial statements factors focusing on four (4) main components in financial statements which are Section 1: Business Revenues, Section 2: Business Expenses, Section 3: Business Assets and Section 4: Business owner's equity and liability. Students were asked to answer the statements in these four (4) different sections using a 5-point Likert scale indicating "1-Poor, 2-Fair, 3-Average, 4-Good and 5-Excellent". The result found that there is value of $0.778 *$ highly acceptable and closely related among all the variables.

Table 2. Reliability test (Cronbach Alpha)

\begin{tabular}{|c|c|}
\hline Variables & Value \\
\hline Business Revenue & 0.750 \\
\hline Business Expenses & 0.766 \\
\hline Business Assets & 0.655 \\
\hline Owner's Equity and Liability & 0.454 \\
\hline Total & $0.778 *$ \\
\hline
\end{tabular}

\subsection{The relationship between prior accounting SPM knowledge and ACC106 Final Exam Result}

Table 3. T-Test result analysis

\begin{tabular}{|c|c|c|c|c|c|}
\hline \multirow{3}{*}{$\begin{array}{c}\text { Final } \\
\text { Group }\end{array}$} & Accounting SPM & N & Mean & Std. Deviation & Std. Error Mean \\
\cline { 2 - 6 } & YES & 71 & 1.28 & .565 & .067 \\
\cline { 2 - 6 } & NO & 453 & 1.64 & .621 & .029 \\
\hline
\end{tabular}


Table 4. Independent Sample Test

\begin{tabular}{|c|c|c|c|c|c|c|c|c|c|c|}
\hline & \multicolumn{2}{|c|}{$\begin{array}{l}\text { Levene's Test } \\
\text { for Equality } \\
\text { of Variances }\end{array}$} & \multicolumn{7}{|c|}{ t-test for Equality of Means } \\
\hline & & \multirow[t]{2}{*}{$\mathrm{F}$} & \multirow[t]{2}{*}{ Sig. } & \multirow[t]{2}{*}{$\mathrm{t}$} & \multirow[t]{2}{*}{ df } & \multirow[t]{2}{*}{$\begin{array}{c}\text { Sig. } \\
\text { (2-tailed) }\end{array}$} & \multirow[t]{2}{*}{$\begin{array}{l}\text { Mean } \\
\text { Diff }\end{array}$} & \multirow[t]{2}{*}{$\begin{array}{l}\text { Std. Error } \\
\text { Diff }\end{array}$} & \multicolumn{2}{|c|}{$\begin{array}{l}\text { 95\% Confidence } \\
\text { Interval of the } \\
\text { Difference }\end{array}$} \\
\hline & & & & & & & & & Lower & Upper \\
\hline \multirow{2}{*}{$\begin{array}{l}\text { Final } \\
\text { Group }\end{array}$} & $\begin{array}{c}\text { Equal variances } \\
\text { assumed }\end{array}$ & 11.548 & .001 & -4.607 & 522 & .000 & -.361 & .078 & -.515 & -.207 \\
\hline & $\begin{array}{c}\text { Equal variances } \\
\text { not assumed }\end{array}$ & & & -4.931 & 98.401 & .000 & -.361 & .073 & -.506 & -.216 \\
\hline
\end{tabular}

An independent samples t-test was conducted to compare performance of students with accounting SPM background and no accounting SPM background. There was a significant difference in the performance for students with accounting SPM background (Mean=1.28, Std. $\mathrm{Dev}=0.565)$ and no accounting SPM background (Mean=1.64, Std. Dev=0.621) conditions; $\mathrm{t}$ $(522)=4.61, p=0.00$. These results indicate that prior experience during SPM really affects the performance of students. Specifically, the result suggests that students with SPM accounting background, performed better and have a high success rate in the basic accounting course, ACC106. This result is in accordance with Illias, Yasoa, Rahman and Razak [14] which implies accounting experiences students perceived more confident in taking the course as compared to non-accounting students. Thus, this suggests that non-experience students must be provided with clear explanation and encouragement to increase their understanding in basic accounting subjects.

\subsection{The relationship between basic understanding on financial statement components and ACC106 Final Exam Result}

This study used linear regression analysis in order to test the relationship between the basic understanding of financial statement components and student performance. The result of multiple regression is presented in the Table 3 below:

Table 3. Multiple Linear Regression

\begin{tabular}{|c|c|c|c|c|c|c|}
\hline Model & $\mathbf{R}$ & $\begin{array}{c}\mathbf{R} \\
\text { Square }\end{array}$ & $\begin{array}{c}\text { Adjusted } \\
\text { R Square }\end{array}$ & $\begin{array}{c}\text { Std. Error of } \\
\text { the Estimate }\end{array}$ & F & Sig \\
\hline 1 & $.111^{\mathrm{a}}$ & .012 & .010 & 15.585 & 6.493 & .011 \\
\hline
\end{tabular}

The above table revealed $\mathrm{R}^{2}$ value, adjusted $\mathrm{R}^{2}$ value, $\mathrm{F}$ statistic and sig $\mathrm{p}$ value. Adjusted $\mathrm{R}^{2}$ value indicated the percentage of independent variables that explained the dependent variable. In overall, the adjusted $\mathrm{R}^{2}$ of .010 has indicated that only $1.0 \%$ variation in the ACC106 final exam result was explained by basic understanding on financial statement components. In addition, adjusted $\mathrm{R}^{2}$ values were supported with $\mathrm{F}$ statistic values; $(\mathrm{F}=6.493)$. From the regression table, the findings exhibited a significant relationship between basic accounting understanding and students' performance in ACC106 subject. This was supported by the significant value of .011 presented that the model was significant at $1 \%$ level. Thus, the result suggests that basic understanding in the financial statement components significantly affect the performance of non-accounting students. Ismail \& Kasim (2014) revealed that prior academic 
results have a positive significant impact on non-accounting students' performance. They found that students who are taking other majoring courses can obtain a good result in accounting subjects provided they are academically good in other subjects. Therefore, understanding the basic financial component is essential in order for students to excel in accounting.

\section{Conclusion}

Graduates nowadays should focus more on other opportunities besides becoming a job seeker as the employment rate in Malaysia keeps increasing from time to time. Graduates should find ways to become a job creator or an entrepreneur to accelerate Malaysian economies. Accounting is undeniably important for all students to equip themselves with financial literacy when they want to start up their own business. Most other universities discovered that the failure rate of accounting subjects in their universities are quite high as the students feel that the subject is irrelevant to their main discipline. However, this study revealed that $93 \%$ of the nonaccounting students in Universiti Teknologi MARA, Jasin Campus had performed very well in the accounting subject. 524 students from Diploma in Science Computer (CS110) and Diploma in Planting Industry Management (AT110) had responded to the survey questionnaire. Students who have taken the 'Prinsip Perakaunan' subject during their SPM level which could be an advantage to them. The subtopics like Accounting Concept, Journals, Ledgers, Trial Balance, Financial Statement, Adjusted Financial Statement, Bank Reconciliation, and Accounting Ratio for sole traders have been embedded in ACC106 subject. The study found that from the t-test with probability $=0.00$, the result suggests that students with SPM accounting background, performed better and have a high success rate in the basic accounting course, ACC106. Therefore, we conclude that the main factor that contributes to the flying colours result of accounting subjects among non-accounting students in Universiti Teknologi MARA, Jasin Campus is because their prior accounting SPM knowledge really contributes to their better achievement in their study.

Furthermore, the other factor that contributed to the success rate for non-accounting students in Universiti Teknologi MARA, Jasin Campus is because of their good understanding in components of financial statements. The four (4) main components in financial statements are (1) Business Revenues, (2) Business Expenses, (3) Business Assets and (4) Business owner's equity and liability. Based on Multiple Regression Test that has been performed, the results revealed that the adjusted $\mathrm{R}^{2}$ value is 0.01 that indicates the basic understanding in the financial statement components significantly affect the performance of non-accounting students. Therefore, the results suggest that in order for the students to succeed and become a good entrepreneur, the students should equip themselves with good accounting knowledge and excel in accounting courses. Students need to really understand the main component of financial statements so that they can manage their business very well in future.

This paper has some limitations. This study has been carried out just on the Faculty of Plantation and Agrotechnology and Faculty of Computer Science and Mathematics. We also consider that the research should include other personal factors such as students' attitudes, family supports, peer pressure and university facilities. Further research could also address pre and post type of questionnaires to measure the level of students' understanding on the subject matter. We finally hope that in future research, there will be collaboration with other universities and branches to expand the number of samples and perform a wider range of study. 


\section{References}

[1] N. T. Sazali, “A Statistical Snapshot of Youth Unemployment," Khazanah Res. Inst., vol. 7, no. 19, 2019.

[2] The Star Online, "Protégé rolls out job traning events. April 2019," 2019. [Online]. Available: https://www.thestar.com.my/news/nation/2019/04/08/protege-rolls-out-job-training-events/.

[3] A. U. Umeji and C. A. Obi, "Cost accounting skills needs of small business operators," Am. J. Ind. Bus. Manag., vol. 2014, 2014.

[4] C. A. Malgwi, "Discerning Accounting and Non-Accounting Students'perceptions in the First Course in Accounting as a Proxy for Separate Course Delivery," Glob. Perspect. Account. Educ., vol. 3, p. 67, 2006.

[5] J. P. Jones and K. T. Fields, "The role of supplemental instruction in the first accounting course," Issues Account. Educ., vol. 16, no. 4, pp. 531-547, 2001.

[6] J. Cohen and D. M. Hanno, "An analysis of underlying constructs affecting the choice of accounting as a major," Issues Account. Educ., vol. 8, no. 2, p. 219, 1993.

[7] M. A. Geiger and S. M. Ogilby, "The first course in accounting: students' perceptions and their effect on the decision to major in accounting," J. Account. Educ., vol. 18, no. 2, pp. 63-78, 2000.

[8] J. B. Biggs, "The role of metalearning in study processes," Br. J. Educ. Psychol., vol. 55, no. 3, pp. 185-212, 1985.

[9] W. H. Zukowska, "Essential subject matter for a one-year basic accounting course offered to nonaccounting majors," Account. Rev., vol. 36, no. 3, pp. 481-487, 1961.

[10] V. Feast, B. Kokkinn, J. Medlin, and R. Frangiosa, "Accounting for student diversity," in HERDSA Annual International Conference, 1999, pp. 12-15.

[11] G. S. May, F. W. Windal, and J. Sylvestre, "The need for change in accounting education: an educator survey," J. Account. Educ., vol. 13, no. 1, pp. 21-43, 1995.

[12] S. Z. Ahmad and S. R. Xavier, "Entrepreneurial environments and growth: evidence from Malaysia GEM data," J. Chinese Entrep., 2012.

[13] H. Matlay, "Researching entrepreneurship and education: Part 1: what is entrepreneurship and does it matter?," Educ. Train., 2005.

[14] A. Illias, M. R. Yasoa, R. Abd Rahman, and M. Z. Abd Razak, "The Study of Students' Perception towards Principle of Accounting (PA): A Survey Among Business Students," Int. Bus. Educ. J., vol. 2, pp. 53-66, 2009.

[15] L. M. Tan and F. Laswad, "Students' beliefs, attitudes and intentions to major in accounting," Account. Educ. an Int. J., vol. 15, no. 2, pp. 167-187, 2006.

[16] W. E. Gist, H. Goedde, and B. H. Ward, "The influence of mathematical skills and other factors on minority student performance in principles of accounting," Issues Account. Educ., vol. 11, no. 1, p. 49, 1996.

[17] R. K. Eskew and R. H. Faley, "Some determinants of student performance in the first collegelevel financial accounting course," Account. Rev., pp. 137-147, 1988.

[18] C. B. Lloyd and A. Abbey, "Teaching elementary accounting to non-accounting majors," Am. $J$. Bus. Educ., vol. 2, no. 2, pp. 23-30, 2009.

[19] S. Muda, A. H. Hussin, H. Johari, J. M. Sapari, and N. Jamil, "The key contributing factors of non-accounting students' failure in the introduction to financial accounting course," ProcediaSocial Behav. Sci., vol. 90, pp. 712-719, 2013.

[20] M. J. R. Menéndez, E. U. Grande, P. L. Sánchez, and M. M. Camacho-Miñano, "Motivation and learning strategies in accounting: Are there differences in English as a medium of instruction (EMI) versus non-EMI students?," Rev. Contab. Account. Rev., vol. 21, no. 2, pp. 128-139, 2018.

[21] S. Ismail and N. Kasim, "Accounting for non-accounting students: What affects their performance?," J. Tech. Educ. Train., vol. 3, no. 2, 2011.

[22] B. A. Baldwin and K. R. Howe, "Secondary-level study of accounting and subsequent performance in the first college course," Account. Rev., pp. 619-626, 1982.

[23] U. Sekaran and R. Bougie, Research methods for business: A skill building approach. John Wiley \& Sons, 2016. 